\title{
What is a treaty?
}

\author{
Michael Dodson
}

A treaty is a settlement or agreement arrived at by treating or negotiation. A treaty gives rise to binding obligations between the parties who makes them. It acts to formalise a relationship between the parties to the agreement(s).

In international law the word treaty has been used to cover a variety of international agreements. The Vienna Convention on the Law of Treaties of 1969 is the international codification of the practice of treaty making previously regulated by the Customary Rules of International Law. The Convention was concluded in Vienna on 23 May 1969 and entered into force on 27 January $1980 .{ }^{1}$ The Convention, to which Australia is a party, defines a treaty as an agreement whereby two or more nation states establish, or seek to establish, a relationship between themselves, imposing binding obligations on themselves and governed by international law. (A short overview of the Convention is at Annex 1.)

The term treaty has been used in the domestic context on occasion to describe arrangements between individuals, for example in conveyancing for the sale and purchase of property. A domestic treaty would by description be bound by domestic law alone and not be subject to international scrutiny.

The word 'treaty' covers a range of ideas and concepts, including, a contract or compact, a covenant, an agreement, a settlement or international arrangements between nation states. In so doing, it acts to regulate a variety of relationships depending on the nature of the relationship.

The treaties of North America between First Nations or First Peoples (sometimes referred to as 'Indians') and the British in the prevailing legal discourse are not considered international treaties in the sense of agreements between independent and sovereign nations. What most of the treaty documents did express is the notion that the Indians constituted separate and sovereign peoples who had their own laws, and were capable as nations and tribes of forming and breaking their own alliances with others, including the colonial powers, and who also had national or tribal territories under their control. Thereby, acknowledging that there is a distinct relationship between the two groups defined by agreement(s).

The legal discourse mentioned above, has arrived at its present place in a journey over several centuries in what Martinez Cobo describes as the process of domesticating relations with Indigenous peoples.

\footnotetext{
${ }^{1} 1155$ UNTS 331
} 
This process essentially was (and still is!) part and parcel of the colonisation process. The European colonising powers (and their successors) sought to transform the status of Indigenous sovereign nations into state domesticated entities. This was attempted in various ways.

To divest Indigenous peoples of their sovereign attributes the main weapon utilised was to strip them of their jurisdiction over their ancestral lands and refuse to recognise their societal organisation and status as subjects of international law.

Whatever the accepted legal position comes to be will not then, as it is not now, be a position that is shared by Indigenous First Nations who are party to such treaties.

A treaty, therefore, is an agreement between two parties who seek to have their relationship with each other spelt out. It would therefore be a recognised relationship bound by the specific principles agreed to by the parties.

Principles underlying a treaty may include:

- recognition of Aboriginal and Torres Strait Islander peoples as the first peoples of Australia and of the distinct rights which flow from this;

- agreement to the necessary reforms for a more just society; and

- the setting of national standards to inform local or regional treaties and agreements.

The international legal meaning of treaties is a position clearly and unequivocally already adopted by the present Australian government as reason for rejecting calls for a treaty. It is obvious that in light of such entrenched attitudes the term treaty must be viewed in the broadest possible sense and efforts made to build confidence in the process (and its ultimate objective) on all sides. Martinez Cobo rightly noted in his treaty study that one should avoid making oneself a prisoner of existing terminology. ${ }^{2}$

What is required is innovative thinking. To put Martinez another way, a Eurocentric historiography of treaties must be put to rest if we are to progress to new treaty making.

\section{Why do we need a treaty?}

Unlike Canada, the United States and New Zealand, Australia has never formally recognised a treaty with Indigenous peoples. Although there were attempts made by people such as Augustus Robinson and Batman, these were never formally recognised nor upheld by the British Colonial powers at the time.

Aboriginal people did have recognised customs and power structures (and still do) that recognised treaties in a variety of forms. This has been clearly noted by Augustus Robinson, who answered an advertisement in the local newspaper to treat with the Tasmanian Aborigines. Clearly, this establishes a link to the type of relationship that existed, at the time of the first contact, between Aboriginal people and the 'settlers'. Thus, drawing attention to the fact that a treaty was seen as a necessary way of defining the relationship between Aborigines and the settlers. And, as such, clearly highlighting that the settlers recognised as early as 1820 that a treaty was of value to the relationship as it was their belief that it would stem the violence and deprivation that Aborigines were suffering from first contact.

\footnotetext{
${ }^{2}$ Martinez Cobo 1987: Add.4.
} 
This is significant in a contemporary setting as it points to the way in which Aboriginal people have been disenfranchised by the tide of history. First, on the basis that their rights have never been formally recognised by the settlers or past government. Second, their rights have been affected by the way in which the relationship has been one sided. History shows that Aboriginal people have been painted in a certain light. Often portrayed as the 'native savages' with no concept of 'civilised' customs. This has been misleading, to both the Aborigines of the past and those of the present. History, in a sense, has been the victimiser (for want of a better term) of Aboriginal people simply by maintaining the construct of Aboriginal people as native savages.

A treaty acts both to restore the lost and suppressed dignity, while defining the Aborigines in what should be seen as a true sense.

Arguably, a treaty could have recognised and protected

Indigenous rights and led to a just Constitutional basis for the Australian Federation.

For example, Aboriginal and Torres Strait Islander peoples were completely overlooked as relevant parties in the formation of the Australian Federation. If a treaty had been in place, and constituted by the principles noted above, the structure of Federation would no doubt have incorporated Aboriginal rights and position in the Federal system. In Australia, it was not until the Mabo decision that the government recognised the property rights of Aboriginal and Torres Strait Islanders. The British, with the exception of Australia, recognised these rights in all its other colonies.

The basis of British sovereignty up until the Mabo decision relied on a ruling in 1889 of the Judicial Committee of the Privy Council, ${ }^{3}$ which said that Australia was not occupied by conquest or cession but rather it was practically unoccupied, without settled inhabitants or settled law at the time it was peacefully annexed. This is essentially the doctrine of terra nullius, which the High Court, in the Mabo judgment, overturned.

The Mabo decision has not delivered a just settlement of the historical grievances of Aboriginal and Torres Strait Islanders. These claims are not only defined in terms of meeting the physical needs of Indigenous peoples but they also have for Aboriginal and Torres Strait Islanders a moral dimension.

The moral component will never be met by better informed government policies or programs of service delivery which focus on health, housing, education, housing etc. The so-called practical reconciliation. To cater for the moral imperatives there has to be a recognition and acceptance by government of two necessary truths:

- Aboriginal and Torres Strait Islander societies have been injured and harmed throughout the colonisation process and just recompense is owed; and

- The status of Aboriginal and Torres Strait Islander peoples as first peoples and the distinctive rights and special status based on prior occupation that flow from that.

Intensive government programs aimed at bringing about equality with other citizens will not, of itself, provide justice for Indigenous Australians. Some still believe this is a form of compensation for past injustices. This approach ignores two important issues, namely the

\footnotetext{
3 Privy Council in Cooperv Stuart (1889) 14 AC 286 at 291; Mabo v Queensland (no 2) 175 CLR 1
} 
adequacy of the compensation and the right of peoples to self-determination. This 'welfarist' approach is just as sinister and destructive as the older paternalistic policies of assimilation.

Culture and identity is every inch of our land and every inch of our history.

The time is right to talk about a treaty with the approach of the Centenary of Federation. Even the word, 'federate', derives from the Latin word, foedere: to make a treaty.

A recent AC Nielsen Age poll showed that $53 \%$ of Australians are ready to embrace the concept of a treaty.

A national treaty here will reflect an Australia that has matured as a nation. It is important to realise that a national treaty does not stop Indigenous communities and other local, regional, state and territory stakeholders from signing treaties with each other at those levels.

Finally, and perhaps above all, a treaty or treaties will deliver the ultimate certainty to the relationship between Aboriginal and Torres Strait Islanders and the rest of the country's population.

\section{What are the benefits of a treaty? (Why would the government agree?)}

A properly negotiated treaty will deliver

- agreed standards;

- a framework for settling relationships between Indigenous peoples and governments at local, regional, state, territory and federal levels;

- legal recognition including Constitutional recognition that Aboriginal and Torres Strait Islander peoples have inherent rights which must inform all processes of governments in Australia;

- improved services such as health, housing, education and employment in accordance with the legitimate aspirations of Indigenous peoples; and

- certainty.

\section{Australian law and the legal framework for a treaty}

There are perhaps four ways in which a treaty could be negotiated in Australia between Indigenous peoples and the Commonwealth Government. These are:

- An agreement under international law in the form of a treaty

- An agreement that is supported by the Constitution

- An agreement that is supported by legislation

- A simple agreement

I discuss below these options for a legislative framework, however I would urge that a single treaty may not suffice.

\section{An agreement under international law in the form of a treaty}

The immediate issue implicit in this approach is the continued existence of Aboriginal and Torres Strait Islander sovereignty as this option is a proposition that would have two sovereign parties: the Commonwealth of Australia and the Aboriginal and Torres strait Islander peoples would enter an agreement enforceable under international law. 
Apart from the need to be in writing this approach poses some difficulties in the Australian domestic political context. Not only do the parties have to have the capacity to conclude treaties under international law but they must also be sovereign entities possessing international personality or status. The Commonwealth of Australia is obviously regarded internationally as a sovereign entity and possesses international personality. This cannot, as a matter of reality, be said to describe the status of Indigenous Australians.

\section{An agreement that is supported by the Constitution}

One option to secure a legal treaty is to include the entire text of the document in the Australian Constitution. Such a proposal could set the basis of relationships between the Commonwealth and Aboriginal and Torres Strait Islander peoples and how they would be conducted for the future.

Such an approach has its advantages, for example in providing certainty, but could prove to be inflexible, difficult to change or to remove problems that may be encountered in operation. Obtaining approval for such a proposal would also be very difficult. A bare statement of principles, perhaps providing a framework for the future relationship, might gain approval from the electors. However, any detailed text would be next to impossible to get into the Constitution given the history of failure of referenda in Australia.

Agreeing on the wording and content appears the most confronting task. These matters would first have to receive support from Indigenous peoples. A bill for a law is then required from the Federal Parliament followed by a majority of people in a majority of states voting in favour.

Another Constitutional option is to insert a special section into the Constitution, which would give a broad enabling power to the Commonwealth Parliament to negotiate a treaty or treaties with representatives of Aboriginal and Torres Strait Islander peoples. This could be based on the present Section 105A as a model. This section of the Constitution provides as follows:

Agreements with respect to State debts (Inserted by No 1.1929, s.2.) 105 A.

(1) The Commonwealth may make agreements with the States with respect to the public debts of the States, including -

(a) the taking over of such debts by the Commonwealth;

(b) the management of such debts;

(c) the payment of interest and the provision and management of sinking funds in respect of such debts;

(d) the consolidation, renewal, conversion, and redemption of such debts;

(e) the indemnification of the Commonwealth by the States in respect of debts taken over by the Commonwealth; and

(f) the borrowing of money by the States or by the Commonwealth, or by the Commonwealth for the States.

(2) The Parliament may make laws for validating any such agreement made before the commencement of this section. 
(3) The Parliament may make laws for the carrying out by the parties thereto of any such agreement.

(4) Any such agreement may be varied or rescinded by the parties thereto.

(5) Every such agreement and any such variation thereof shall be binding upon the Commonwealth and the States parties thereto notwithstanding anything contained in this Constitution or the Constitution of the several States or in any law of the Parliament of the Commonwealth or of any State.

(6) The powers conferred by this section shall not be construed as being limited in any way by the provisions of section one hundred and five of this Constitution.

If such a proposal received support from the electors at a referendum it would give the Commonwealth Parliament plenary powers to enter such treaties. It potentially gives great security to Aboriginal and Torres Strait Islander peoples and would not require the support (although desirable) of the States. It would also avoid the need for the Commonwealth to have to rely on some other (uncertain) enabling power presently existing in the Constitution, like Section 51. (xxvii).

The High Court of Australia has said, referring to sub-section 5 of Section 105A, that:

... the effect of this provision is to make any agreement of the required description obligatory upon the Commonwealth and the States, to place its operation and efficacy beyond the control of any law of any of the seven Parliaments, and to prevent any Constitutional principle or provision operating to defeat or diminish or condition the obligatory force of the Agreement.

A new Section 105B could be perhaps inserted which would enable the Commonwealth to have the power to make the treaties as presently spelt out in the first paragraph of 105A. This paragraph would then be followed by a non-inclusive list of those things that might form the content and substance of the treaties, in very broad terms.

The terms of the treaties could set other requirements, for example, forms of dispute resolution and the power to vary the treaty provision by the parties. The new 105B would also require an automatic validation of the treaty or treaties entered into before the new section took effect. This would allow existing agreements, if so desired, to be brought under the new section. There could also be a power for the parliaments to pass laws enabling them to carry into effect the terms of the treaty or treaties; this would mean the Commonwealth could authorise the States, in certain agreed circumstances to exercise the Commonwealth power.

A possible 105B:

(1) The Commonwealth may make a treaty or treaties with persons or bodies recognised as representatives of Aboriginal and Torres Strait Islander peoples of Australia with respect to the status and rights of those people within Australia including but not limited by the following:

(a) restoration to Aboriginal and Torres Strait Islander peoples or to some of them of their lands which were owned and occupied by them prior to 1770; 
(b) compensation for the loss of any land incapable of being restored to the Aboriginal and Torres Strait Islander peoples or some of them;

(c) matters of health, education, employment and welfare;

(d) matters of political status, representation and organization, including self-government;

(e) matters of inherent sovereignty and the sharing of sovereignty;

(f) matters of language, culture, heritage and intellectual and cultural property;

(g) the law, including Aboriginal and Torres Strait Islander law and custom, relating to the exercise of judicial power by the Commonwealth of Australia or any State or any Territory within Australia;

(h) Any other matter identified by Aboriginal and Torres Strait Islander peoples in relation to their status as first peoples and nations.

(2) The Parliament shall have the power to make laws for the validating of any such treaty or treaties made before the commencement of this section. Such laws shall not be altered, amended, rescinded or repealed by the Parliament without the free and informed consent of the Aboriginal and Torres Strait islanders party to the treaty or treaties as well as a two-thirds majority vote of the members of both houses of the Parliament entitled to vote.

(3) Any treaty or treaties made may be varied or rescinded by the parties thereto and as such shall supersede any prior treaty or treaties for the purposes of this section.

(4) Subject to sub-section (2), the Parliament shall have the power to make laws for the implementation by the parties of such treaty or treaties.

(5) Any laws passed under clauses 2 and 4 shall be binding upon the Commonwealth, the States and Territories within Australia, notwithstanding anything contained in this Constitution or the Constitutions of the several states or the self governing laws of any territory or any law of the Commonwealth, or of any State or territory.

(6) Any variation or alteration or rescinding of this section shall occur in the following manner

(a) notwithstanding section 128 a bill for a law for a referendum shall not be introduced into the Parliament without the Parliament having obtained twothirds majority support of the Aboriginal and Torres Strait Islander peoples;

(b) the terms of the treaty or treaties permits such alteration, amendment or rescinding, and if so, are complied with.

Sub-section (5) would give full force of the Constitution to laws passed to effect the treaty or treaties.

This approach removes the complexity of trying to incorporate the text of a treaty into the Constitution. 


\section{An agreement that is supported by legislation}

Any legislation passed by the Commonwealth parliament must fall within a scope of power given to the parliament by the Australian Constitution. There are two potential 'heads' of power. Section 51 (xxvii) (the 'races power') and Section 51 (xxix) (the 'external affairs power')

\section{The 'races power'}

The Commonwealth Parliament has passed laws like the ATSIC Act, the NT land rights Act and the Native Title Act using the power given to it under the Constitution via Section 51 (xxvii):

51. The Parliament shall, subject to this Constitution, have power to make laws for the peace, order, and good government of the Commonwealth with respect to:

(xxvi) the people of any race for whom it is deemed necessary to make special laws:

Prior to the referendum in 1967 the Commonwealth Parliament had no power under the Constitution to make laws for the Aboriginal and Torres Strait Islander 'races'. The power since then has sometimes been used in a discriminatory fashion. For example the Hindmarsh Island ${ }^{4}$ and Native Title Act amendment legislation. ${ }^{5}$ It should be noted the Council for Aboriginal Reconciliation in its final report to the Federal parliament has recommended a new section be inserted into the Constitution making it unlawful to adversely discriminate against people on the grounds of race. ${ }^{6}$

There appears to be no doubt that the Commonwealth Parliament has the power under this section of the Constitution to make special laws, without predetermining the content of what they might contain, to give effect to a treaty or treaties.

There is an obvious political limitation in the use of this power most recently exemplified by the amendments by the present government to the Native Title Act. The vulnerability arises from the capacity of later parliaments (depending on which political party or parties has a temporary majority) to substantially repeal or amend such legislation. This potential political exposure represents a substantial impediment to the use of the existing Constitutional power under this 'head' to implement a treaty or treaties.

\section{The 'external affairs power'}

The Commonwealth Parliament has power under the Constitution to make laws with respect to external affairs under Section 51 (xxix), which reads as follows:

The Parliament shall, subject to this Constitution, have power to make laws for the peace, order, and good government of the Commonwealth with respect to:

(xxix) External Affairs.

This section gives the Parliament the power to enact legislation governing and regulating all Australia's relations with other countries.

\footnotetext{
${ }^{4}$ Hindmarsh Island Bridge Royal Commission (1996) AILR 46; (1996) ALIR 315.

${ }^{5}$ Native Title Amendment Act 1998 (Cth).

${ }^{6}$ Final report of the Council for Aboriginal Reconciliation, 2000: recommendation 3.
} 
This is a very broad power and generally the conduct of external affairs does not require legislative action as these matters are usually accomplished by executive action. A law is required however if that executive action requires an appropriation of money and/or a need to put into domestic or internal effect arrangements made as a result of the conduct of external affairs. For example the accession by Australia to the Convention For the Elimination of all Forms of Racial Discrimination was an executive decision and internally given effect to by the enactment of the Race Discrimination Act 1975.

It is arguable that this power enables the Commonwealth Parliament to make laws on an indefinite array of subjects provided each met the description of an external affair. A treaty or treaties with the Indigenous peoples of Australia could fall within such a description. For example, the poor socio-economic circumstances of Aboriginal and Torres Strait Islanders are of concern to many countries with strong links to Australia. If the reason (in part) is to allay these concerns and improve international relations with these countries then it could arguably be described as an external affair (given domestic effect to by the treaty or treaties). What requires demonstration is that the subject matter of any legislation is a matter for international concern.

\section{Reference of powers by states}

The Commonwealth Parliament can enact laws by reference to matters referred to it by state parliaments. The most recent example, perhaps, concerning Indigenous issues, was the Framlingham and Lake Tyers Act of the Victorian Parliament. ${ }^{7}$

Section 51. (xxxvii) of the Constitution provides:

51. The Parliament shall, subject to this Constitution, have power to make laws for the peace, order, and good government of the Commonwealth with respect to:

Matters referred by the Parliament or Parliaments of any State or States, but so that the law shall extend only to States by whose Parliaments the matter is referred, or which afterwards adopt the law:

The fourth way in which a treaty could be negotiated in Australia between Indigenous peoples and the Commonwealth is by simple agreement.

\section{A simple agreement}

A treaty or treaties could be negotiated in the form of a simple agreement, placed in the realm of the statutory and common law of contract.

The contract or agreement could create legally enforceable rights and obligations. This is essentially the way in which the United States of America dealt with Native American tribes between 1788 and 1842 (242 treaties made during that time). The power to make treaties in the United States comes from Article I section 8 of the American Constitution, which empowers the United States Congress:

to regulate Commerce with foreign Nations, and among several

States, and with the Indian Tribes;

${ }^{7}$ Aboriginal Land (Lake Condah and Framlingham Forest) Act 1987, 27/1, 9/2 
In 1871 the United States Congress passed the Indian Appropriation Act it provided that:

No Indian nation or tribe within the territory of the United States shall be acknowledged or recognised as an independent nation, tribe or power with whom the United States may contract a treaty ...

The whole approach of the United States up until then (from 1778) was to acquire Indian lands by purchase through 'treaties'. The status of these agreements never amounted to instruments governed by international law - they were more in the nature of contracts for the sale of land. This of course, in almost every case, was not the way they came to be regarded by the various Native American nations. Essentially, at least from the point of view of the Congress, they were domestic agreements governed by domestic law.

In the Marshall cases ${ }^{8}$ the concept of domestic dependent nations was denominated by the Chief Justice. This placed the relationship between the United States and the Indian nations as one that resembled that of ward to guardian. Subsequently confirmed by the Indian Appropriation Ac of 1871.

Canada's Royal Proclamation of $1763^{9}$ guaranteed the protection of the Indians under the British crown. The Proclamation acknowledged Indian interests in land the crown having exclusive rights to purchase which it proceeded to do so by way of treaties. Sixty-seven such treaties were concluded between 1725 and 1919, they were formal written agreements to which both parties attached great significance at the time. Legally these treaties, like those in the United States have come to be regarded as domestic arrangements without international character.

Section 35 of the Canadian Constitution provides that:

The existing Aboriginal and treaty rights of the Aboriginal peoples of Canada are hereby recognised and affirmed.

This section was inserted into the Canadian Constitution in 1982, well after the original treaty making era, and not only does it afford protection for those pre-existing treaty rights for Indigenous Canadians it has also ushered in a new era of treaty making. This new treaty making in Canada has met with varying success and, in some instances the failure or complete breakdown in negotiations (compare the Nishga agreement in $1996^{10}$ and the breakdown of negotiations with the Dene Nation in the late 1980's). ${ }^{11}$ If there is one important lesson to be learned from the recent Canadian experience for Australian context if we are to progress to our first era of treaty making it is the following. Great attention and diligence must be attached to the importance and potential utility of establishing sound; equitable 'ground rules' for the negotiations required drafting and concluding treaties.

In 1840 the British government entered the Treaty of Waitangi with the Maoris of the North Island of New Zealand, the South Island by assertion of British right of discovery. The Waitangi treaty purported to do three things (contested by the Maori):

- Maori acceptance of British sovereignty;

- British crown's protection of Maori possessions; and

- the Crown having the exclusive right to purchase Maori land.

\footnotetext{
${ }^{8}$ Especially 6 / 6 Cherokee Nation v. State of Georgia (1831)

${ }^{9}$ Generally known as the Royal Proclamation of 1763 (7 October 1763)
}

\footnotetext{
${ }^{10}$ Nishga Framework Agreement, signed 12 February 1996

${ }^{11}$ See http://www.denenation.com/
} 
In 1975 the Treaty of Waitangi Act was passed to:

Observance and confirmation, of the principles of the Treaty of

Waitangi by establishing a tribunal to make recommendations on claims relating to the practical application of the treaty ...

\section{How is sovereignty to be understood?}

Sovereignty means an indivisible and exclusive power and capacity for self-government along with international recognition of that power. In international law any challenge to the basis of sovereignty (or assertion of it) is to be answered, if possible, by reference to the Inter-Temporal law. That, briefly, means that any questions about the legitimacy of the assertion of sovereignty has to be interpreted by reference to the law in force during that period. For Australia, this is the time of colonisation.

The 'discovery' and 'settlement' of Australia occurred in stages. Captain James Cook was instructed in 1768 to discover what was then known as New Holland. He landed at Botany Bay on 29 April 1770 and by 22 August 1770 had purported to take possession of the entire Australian East Coast on behalf of the British King.

The First Fleet arrived on 26 January 1778 and Governor Phillip raised the British flag on 7 February 1778. The colonisation of the continent had begun. Captain Fremantle took formal possession of Western Australia on 2 May 1829. The first British 'settlers' arrived in 1829 and 1830.

What then were the international rules of acquisition of new territories by European colonising powers in 1770 and immediately thereafter?

There are basically five ways in which new territories can be acquired in international law:

1 Cession

2 Occupation

3 Prescription

4 Accretion

5 Conquest

In the case of Australia occupation or settlement of land that was said to be terra nullius is of relevance here. Although the High Court rejected the notion of terra nullius in its Mabo decision in 1992, settlement is the prevailing view as the source of Australian sovereignty.

Between the sixteenth and nineteenth centuries there were basically three main propositions put forward on the existence or otherwise of the sovereignty of Indigenous peoples.

1 recognition that Indigenous entities had complete sovereignty over their territories

2 Indigenous entities had a restricted or conditional sovereignty over their territories and,

3 total rejection of such sovereignty.

Imperial European powers generally acquired their possession by cession or conquest. In Africa for example, the predominant mode of acquisition became cession and hundreds of treaties 
were concluded between Europeans and African Nations. Where African Nations were not prepared to settle treaties military force was used. One example is the West African Kingdom of Asante. The British fought three wars and it was not until 1900 that their superior military might overwhelmed the Kingdom. Similar modes of colonisation occurred in Asia.

In New Zealand cession was the mode of acquisition used by the British in the terms of the Treaty of Waitangi Act. Article 1 reads:

The chiefs of the Confederation of the United Tribes of New Zealand, and the separate and independent chiefs who have not become members of the Confederation cede to Her Majesty the Queen of England, absolutely and without reservation, all the rights and powers of sovereignty which the said Confederation of individual chiefs respectively exercise or possess or may be supposed to exercise or possess over their territories as the sole sovereigns thereof.

It should be noted that since European colonising powers began the practice of treaty making with Indigenous peoples there have been substantial differences in the construction of the provisions of these treaties between the parties, particularly as to those relating to the object and purpose of the treaty concerned.

For example, the Maori and Pakeha constructions of the Waitangi Treaty differ on crucial matters including alleged 'transfers' of governance/sovereignty powers and 'land title' to nonMaori settlers, as well as to the actual purpose of the treaty itself. In fact, the version written in the Maori language bears little resemblance to the one written in the English language.

In North America cession was the preferred mode and in most cases in Central and South America conquest was resorted to. (The Mapuche Parlamentos in Chile are one of a number of exceptions in point).

Territories designated terra nullius during the colonisation period were a rarity. Wherever there were people with some form of socio-political organisation the European colonists generally acquired territories by conquest or cession.

When Captain Cook departed England to 'discover' Australian his instructions said:

You are also with the consent of the natives to take possession of convenient situations in the country in the name of the King of Great Britain or if you find the country uninhabited take possession for His Majesty by setting proper marks and inscriptions as first discoverers and possessors ... ${ }^{12}$

Cook ignored the natives, cut an inscription in a tree, raised the British flag, violated international law of the time and disregarded the instructions of his superiors.

Cook seems to have regarded Australia as terra nullius and the claim was based on an assertion that Aborigines lacked political organisation with settled law. This assertion relies on the erroneous view that there was (or had to be in European terms) one single Aboriginal nation

${ }^{12}$ Captain Cook - the first voyage (2), available at http:/www.library.ucla.edu/libraries/special/scweb/cookcheck3.htm 
which is a nonsense there were over 500 nations with established law and political systems, (the lower Murray tribes were joined in a confederacy!) which was all that was required in international law at the time.

Australia was the exception to British behaviour elsewhere at the time, particularly Africa.

What then was the situation in Australia when the convict colony was established in Sydney Cove? Were the people living in a territory politically organised so as to qualify, in European terms, as territorially sovereign?

It is now beyond argument that although Aboriginal societies did not have centrally organised governments in the European sense at the time, nevertheless there is clear and surviving evidence that in most Indigenous societies in this country there was a clearly demarcated line of authority. Religious leaders exercised (and still do) authority which extends into secular areas. There were, and are, no hard rules demarcating the religious from the secular in Aboriginal societies, where the law is paramount and used to maintain order. There can be no doubt that Aboriginal societies had the means of regulating themselves long before the arrival of Europeans who refused to see these structures.

These types of systems mentioned above have been referred to as segmentary lineage systems and were recognised by the British in Africa during the colonising era. (It was also a system well recognised in South America.) The British did not settle Iboland (later Biafra and now part of Nigeria) by occupation despite the fact the Ibos had no kings or princes. There are numerous other African examples where peoples without centralised systems did not lose their lands because they were 'ownerless'. The practice in Australia or settlement theory is indefensible.

Conquest also cannot fix the defect. A frontier war raged for over a century. Aboriginal people did not 'peacefully' give up the land: they were killed or forcibly removed from the land by British forces or European colonists. There has been no peace treaty therefore; technically a state of war still exists.

Prescription is likewise no answer. Prescription is the consolidation of possession by the continued, constant and sufficiently long practice of government whereby they could argue convincingly they had the continuous and peaceful display of government. This defence is only open to challenge from another nation state, say if the Netherlands challenged Australian sovereignty over Tasmania because Abel Tasman had 'discovered' it. Australia could, in international law, probably defeat such a challenge.

Peaceful and unchallenged are the operative words here. Aborigines and Torres Strait Islanders have never conceded defeat and have challenged the legality of the Australian foundational sovereignty on numerous occasions in the courts of the colonisers, Mabo and $\mathrm{Coe}^{13}$ two examples. There is also increasing use by Indigenous Australians of international fora to voice protest and objection and to challenge.

The High Court's decision in Mabo although rejecting terra nullius and recognising native title did not (and said it could not) challenge the foundations of present Australian sovereignty. As the court said it was a question not justiciable in municipal courts. How can the court have accepted the validity of Aboriginal and Torres Strait Islander rights to land but not

\footnotetext{
13 Paul Coe v the Commonwealth (1979) 53 ALJR 403
} 
uphold rights of governance? Why the inconsistent allegiance by the court to the 'occupation' 'settlement' fallacy?

Whatever the High Court has left us with post-Mabo as to what is now the foundations of the sovereignty of the Australian nation state is a mystery. The sovereign pillars of the nation state are arguably at the very least, a little shaky legally.

It is important to remember that in modern times sovereignty is rarely vested exclusively in one person or one entity. The feature of modern nation states is a sharing or co-existence of sovereign entities. In Australia since federation it has been divisible between the Commonwealth and the states and territories and local government. The Torres Strait Regional Authority already has a c-existing sovereign responsibility over certain matters.

Internationally there are numerous examples. Nearby Vanuatu was until recently a shared trust territory between the British and the French, the Innuit of Greenland share sovereignty with the Kingdom of Denmark and proposals for shared sovereignty between Israel and the Palestinians is mooted.

The adoption of international treaties requires a level of relinquishment of national sovereignty under the terms of the respective treaties and international law. Australia has been in the business of adopting international treaties for a very long time.

\section{Scope of content}

Matters mentioned in the section above dealing with a broad Constitutional enabling power might form the basis for the content of treaties. What the content of these treaties might be is largely an issue for the negotiating parties, what they can agree on and what their imaginations will allow.

Some of the content might include:

- the prohibition of racial discrimination;

- recognition of the rights of equality;

- recognition of the principle of non-discrimination;

(The ideal situation would be to have these three principles embedded in the Australian Constitution)

- access to education and training;

- employment;

- the recognition of distinct Indigenous identities;

- the protection of laws, cultures, and languages;

- the effective implementation of relevant recommendations from a variety of reports;

- law and justice issues;

- resolution for the stolen generations;

- control, ownership and management of land, waters and resources;

- benefits from resource development;

- economic and social development; 
- reparation, and compensation;

- self-determination;

- self-government; and

- constitutional recognition.

This is by no way intended to be an exhaustive list. The negotiation process must have the flexibility to allow for new or more specific issues to be identified for negotiation in the future.

The identification of the content of treaties might be achieved through agreed processes under a Constitutional mandate as mentioned above, which would allow the parties to reach agreement on principles which would underpin the negotiations.

\section{Acknowledgments}

The author acknowledges the work of the Aboriginal Treaty Committee in the original formulation of the concept of the constitutional entrenchment of a treaty.

\section{References}

Canada 1763, Royal Proclamation of 1763 (7 October).

Canada 1996, Nishga Framework Agreement, 12 February.

Canada re Dene Nation, 1990, http://www.denenation.com

Captain Cook - The first voyage (2), http://www.library. ucla.edu/libraries/special/scweb/cokcheck3.htm

Reconciliation. Australia's Challenge, Final report of the Council for Aboriginal Reconciliation to the Prime Minister and the Commonwealth Parliament, Council for Aboriginal Reconciliation 2000...

Hindmarsh Island Bridge Royal Commission (1996) AILR 46; (1996) AILR 315.

Martinez Cobo, JR, 1987, Study of the Problem of Discrimination against Indigenous Populations, UN Doc. E/CN. 4/Sub.2/1986/7/Add.4.

Vienna Convention on the Law of Treaties 1969, 23 May, 1155 UNTS 331.

\section{Legislation}

Aboriginal Land (Lake Condah and Framlingham Forest) Act 1987.

Indian Appropriation Act 1871 (US).

Native Title Act 1993 (Cth).

Native Title Amendment Act 1998 (Cth).

Race Discrimination Act 1975 (Cth).

Treaty of Waitangi Act 1975 (NZ).

\section{Case law}

Cherokee Nation v State of Georgia (1831) (US).

Cooperv Stuart (1889) (Privy Council)14 AC 286.

Mabo and Ors $v$ The State of Queensland (No 2) (1992)

175 CLR 1.

Paul Coe v The Commonwealth (1979) 53 ALJR 403. 


\section{ANNEX 1}

\section{The Vienna Convention on the Law of Treaties}

The Convention was concluded in Vienna on 23 May 1969 and entered into force on 27 January 1980. The international statement is important because it may provide some assistance and guidance in the formulation of rules as to how a treaty or treaties might be negotiated within the Australian domestic context if that be the path that is eventually adopted.

The Vienna Convention is structured as follows:

The preambular paragraphs deal with the fundamental role of treaties in the history of international relations, and recognise the importance of treaties as a source of international law and as a means of developing peaceful co-operation among nations. They note that the principles of free consent and of good faith and the pacta sunt servanda rule are universally recognised, and affirm that disputes concerning treaties, like other international disputes, should be settled by peaceful means and in conformity with the principles of justice and international law. The paragraphs also recall the Charter of the United Nations, particularly such as the principles of the equal rights and self-determination of peoples, of the sovereign equality and independence of all States, of non-interference in the domestic affairs of States, of the prohibition of the threat or use of force and of universal respect for, and observance of, human rights and fundamental freedoms for all. And finally, the preamble affirms that the rules of customary international law continue to govern questions not regulated by the provisions of the Convention.

In PART I, the INTRODUCTION, a treaty is defined as:

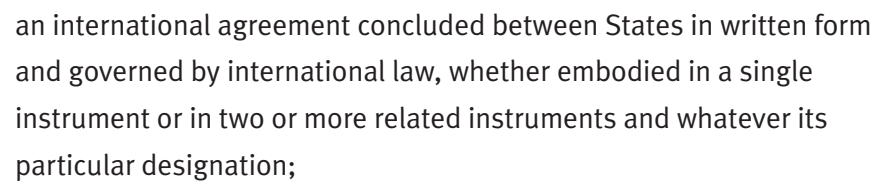

PART II deals with the conclusion and entry into force of treaties and pronounces that:

Every State possesses capacity to conclude treaties.

The Part also deals with the authorisation of acts, the adoption of the text, the authentication of the text, the means of expressing consent to be bound by a treaty and the entry into force of a treaty.

Part III deals with the observance, application and interpretation of treaties. It entrenches the principle of pacta sunt servanda:

Every treaty in force is binding upon the parties to it and must be performed by them in good faith.

Very importantly this part makes it absolutely clear that a State cannot invoke the provisions of its own domestic Constitutional and legal arrangements as justification for its failure to perform a treaty. 
Section 3 of this part deals with the interpretation of treaties:

A treaty shall be interpreted in good faith in accordance with the ordinary meaning to be given to the terms of the treaty in their context and in the light of its object and purpose.

Part IV of the convention deals with the amendment and modification of treaties, the general rule being that a treaty may be amended by agreement between the parties if it is provided for and complies with the Convention and international law. The amendment rules vary slightly so far as multilateral treaties are concerned.

Part V of the Convention relates to Invalidity, Termination and Suspension of the Operation of Treaties. The main provision to note is Article 42.2, which says:

2. The termination of a treaty, its denunciation or the withdrawal of a party, may take place only as a result of the application of the provisions of the treaty or of the present Convention. The same rule applies to suspension of the operation of a treaty.

However, it is also to be noted that Obligations imposed by international law still apply independently of a treaty.

The part also variously provides for the invalidating of treaties through fraud, corruption and coercion to mention the ones of key importance. It is also noteworthy in this context that the Convention entrenches the principle of jus cogens, namely:

A treaty is void if, at the time of its conclusion, it conflicts with a peremptory norm of general international law.

If a new peremptory norm of general international law emerges, any existing treaty, which is in conflict with that norm, becomes void and terminates.

Article 66 of this Part deals with the Procedures for judicial settlement, arbitration and conciliation. Under these provisions an application can be made to the International Court of Justice by a State and the procedure is set out in Annex 1 of the Convention.

Finally part VI of the Treaty is entitled 'miscellaneous provisions' and deals primarily with Cases of State succession, State responsibility and outbreak of hostilities. The last two Parts (Part VII and Viii) deal with administrative and procedural matters such as depository notification, communication and ratification. 